\title{
Efek Nefroprotektif Ekstrak Etanol Bawang Putih (Allium sativum L.) pada Tikus yang Diinduksi Gentamisin
}

\section{Nephroprotective Effect of Ethanolic Extract of Bawang Putih (Allium sativum L.) on Rats Induced by Gentamicin}

\author{
Tanti Azizah Sujono*, Fanny Atika Rizki \\ Departemen Farmakologi dan Farmasi Klinik, Fakultas Farmasi, Universitas Muhammadiyah Surakarta, Jl. A. \\ Yani Tromol Pos I Pabelan Sukoharjo 57162, Indonesia \\ *E-mail: tanti_azizah@ums.ac.id
}

Received: 6 Maret 2020; Accepted: 7 Juni 2020; Published: 3 Juli 2020

\begin{abstract}
Abstrak
Penggunaan gentamisin dapat menyebabkan kerusakan ginjal karena terjadinya akumulasi pada sel-sel epithelial korteks. Akumulasi ini dapat menyebabkan terjadinya peningkatan Reactive Oxigen Species (ROS) yang selanjutnya dapat memicu peningkatan radikal bebas sehingga menyebabkan penurunan fungsi ginjal, yang dapat dilihat dengan parameter BUN (Blood Urea Nitrogen) dan sCr (serum creatinine). Bawang putih (Allium sativum L.) memiliki kandungan senyawa bioaktif, di antaranya alliin, allisin, ajoene, dan allil sistein. Allisin pada umbi bawang putih memiliki aktivitas antioksidan. Penelitian ini bertujuan untuk menilai pengaruh ekstrak etanol bawang putih dalam mencegah penurunan fungsi ginjal akibat induksi gentamisin dengan parameter BUN dan sCr. Metode permodelan tikus nefrotoksik dengan induksi gentamisin $100 \mathrm{mg} / \mathrm{kgBB}$ secara intraperitoneal selanjutnya dicek kadar BUN, sCr 24 jam setelah induksi hari ke-10. Hewan uji dibagi 5 kelompok perlakuan, yaitu kelompok kontrol normal, kontrol negatif (gentamisin), dan tiga kelompok perlakuan dengan dosis 50, 120, dan $300 \mathrm{mg} / \mathrm{kgBB}$ selama 10 hari perlakuan secara bersamaan antara ekstrak dengan gentamisin. Hasil penelitian menunjukkan bahwa ekstrak etanol bawang putih dosis 50,120, $300 \mathrm{mg} / \mathrm{kgBB}$ mampu mencegah penurunan fungsi ginjal akibat pemberian gentamisin secara signifikan jika dibandingkan dengan kontrol negatif $(\mathrm{p}<0,05)$.
\end{abstract}

Kata Kunci: Blood Urea Nitrogen, Allium sativum L., gentamisin, kreatinin, nefroprotektif

\begin{abstract}
Gentamicin can induce damage to the kidney because of the accumulation of epithelial cells in the cortex. This accumulation can cause an increase in Reactive Oxygen Species (ROS), which in turn can trigger an increase in free radicals which causes a decrease in kidney function, which can be seen with Blood Urea Nitrogen (BUN) and $\mathrm{sCr}$ (serum creatinine) parameters. Garlic (Allium sativum L.) contains several bioactive compounds, including alliin, allisin, ajoene, and allil cysteine. The content of allisin has activity as an antioxidant. This study used a nephrotoxic mouse modelling method with $100 \mathrm{mg} / \mathrm{kgBW}$ of gentamicin induction intraperitoneally, then BUN and sCr levels were checked 24 hours after the $10^{\text {th }}$ day induction. This study aimed to determine the effect of garlic ethanol extract in preventing the decline of renal function in rats induced by gentamicin with a parameter of $B U N$ and $s C r$. The animal test were divided into 5 treatment groups, normal control group, negative controls, and three treatment groups at a dose of 50, 120, and $300 \mathrm{mg} / \mathrm{kgBW}$ for 10 days of concurrent treatment between extracts with gentamicin. The results of the study showed that garlic ethanol extract with a dose of 50,120, $300 \mathrm{mg} / \mathrm{kgBW}$ was able to prevent a decrease in kidney function due to the administration of gentamicin significantly when compared with negative controls ( $p<0,05)$.
\end{abstract}

Keywords: Blood Urea Nitrogen, Allium sativum L., gentamicin, creatinine, nephroprotective

\section{PENDAHULUAN}

Ginjal berfungsi dalam mengatur keseimbangan air, konsentrasi garam dalam darah, keseimbangan asam-basa darah, serta ekskresi kelebihan garam dan bahan buangan termasuk zat-zat toksik yang masuk ke dalam tubuh. Oleh karena itu ginjal menjadi salah satu organ target utama dari efek toksik (Pearce, 2013). Tes fungsi ginjal dapat dilakukan dengan mengukur kadar Blood 
Urea Nitrogen (BUN), serum kreatinin ( $\mathrm{sCr}$ ) dan profil urin. Pada ginjal yang sudah tidak berfungsi dengan baik, BUN dan sCr akan tetap tertahan di dalam darah yang akan mengakibatkan terjadinya peningkatan kadar BUN dan sCr. Kadar serum urea atau BUN meningkat pada penyakit ginjal akut dan kronik. Kadar serum kreatinin meningkat ketika terjadi penurunan Glomerular Filtration Rate (GFR) yang signifikan. Sekitar $50 \%$ fungsi ginjal akan menurun sebelum peningkatan kreatinin serum dapat dideteksi. Jadi serum kreatinin dan laju filtrasi glomerulus adalah penanda akhir dari cedera ginjal akut (Gounden and Jialal, 2019). Analisis profil urin dilakukan sebagai data pendukung karena urin merupakan jalur utama ekskresi sebagian senyawa toksik. Secara klinis, adanya sejumlah besar protein dalam urin (proteinuria) merupakan salah satu tanda awal dari hampir semua penyakit ginjal (Gowda et al., 2010)

Pada penelitian ini, digunakan antibiotik gentamisin, merupakan antibiotik golongan aminoglikosida yang mempunyai efek samping nefrotoksik karena dapat menyebabkan nekrosis sel-sel epitel tubulus. Setelah difiltrasi melalui glomerulus, sebagian kecil dari gentamisin akan tertahan pada tubulus proksimal terutama di dalam lisosom, aparatus golgi, dan retikulum endoplasma. Akumulasi ini yang memicu terjadinya gangguan fungsi ginjal (Dehghani et al., 2011). Produksi spesies oksigen reaktif (ROS) juga berperan penting dalam proses nefrotoksisitas gentamisin yang bersifat reversibel. Spesies oksigen reaktif secara langsung mengakibatkan rusaknya molekul seluler termasuk asam nukleat, protein, dan lipid yang dapat memicu terjadinya kematian sel, menyebabkan peradangan dan kontraksi mesangial dan pembuluh darah. Oleh karena itu penggunaan antioksidan untuk mencegah peningkatan ROS di dalam sitosol efektif pada kerusakan ginjal akibat induksi gentamisin (Lopez-Novoa et al., 2011). Bawang putih (Allium sativum L.) mengandung senyawa allisin yang memiliki akitivitas utama sebagai antioksidan (Rahman et al., 2012), menurut penelitian yang sudah dilakukan sebelumnya, kandungan allisin di dalam bawang putih dapat menurunkan kadar BUN menjadi normal yaitu $13,0 \mathrm{mg} / \mathrm{dL}$ (Anusuya et al., 2013).

Pada penelitian ini, digunakan bawang putih yang dapat dimanfaatkan dalam terapi nefrotoksik dengan menggunakan hewan uji tikus. Bawang putih diharapkan dapat melindungi kondisi ginjal tikus akibat induksi gentamisin. Oleh karena itu, perlu dilakukan penelitian lebih lanjut untuk menilai efek nefroproteksi ekstrak etanol bawang putih terhadap fungsi ginjal tikus yang diinduksi dengan gentamisin. Penelitian ini bertujuan untuk menilai pengaruh ekstrak etanol bawang putih dalam mencegah penurunan fungsi ginjal akibat induksi gentamisin dengan parameter BUN dan sCr.

\section{METODE PENELITIAN \\ Bahan}

Bahan-bahan yang digunakan yaitu umbi bawang putih yang diambil dari daerah Tawangmangu, Karanganyar, Jawa Tengah pada bulan Juli 2018. Bawang putih segar lengkap dengan akar dan daunnya di determinasi di Laboratorium Biologi Fakultas Keguruan dan Ilmu Pendidikan Universitas Muhammadiyah Surakarta dengan nomor 045/A.E-I/LAB.BIO/IX/2018; etanol 96\% (teknis), gentamisin sulfat $40 \mathrm{mg} / \mathrm{mL}$ injeksi (PT. Indofarma, Bekasi), $\mathrm{NaCl}$ 0,9\% (teknis), akuades, Reagen Kit Urea FS* (DiaSys), Reagen Kit Creatinine FS* dari (DiaSys), urine strip (Verify), pellet (pakan standar), serta aquadest.

\section{Ekstraksi}

Ekstraksi bawang putih dilakukan dengan metode maserasi menggunakan pelarut etanol 96\%. Umbi bawang putih yang sudah dipisahkan dari kulitnya, dicuci bersih kemudian dihaluskan menggunakan blender. Sebanyak 620 gram bawang putih yang telah halus dimaserasi dengan $2 \mathrm{~L}$ etanol, diaduk selama kurang lebih 15 menit, didiamkan selama 2x24 jam, kemudian disaring. Filtrat 
yang didapatkan selanjutnya dievaporasi dengan rotary evaporator. Ekstrak cair yang dihasilkan dari proses evaporasi dituang ke dalam cawan porselin, diletakkan pada water bath suhu $40^{\circ} \mathrm{C}$ selama 3 hari sampai terbentuk ekstrak kental.

\section{Penentuan dosis ekstrak etanol bawang putih}

Menurut penelitian yang sudah dilakukan sebelumnya, pemberian ekstrak etanol bawang putih dengan dosis $150 \mathrm{mg} / \mathrm{kgBB}$ merupakan dosis efektif karena dapat menurunkan kadar Blood Urea Nitrogen menjadi normal (Anusuya et al., 2013). Maka, digunakan $50 \mathrm{mg} / \mathrm{kgBB}$ sebagai dosis terendah dan $300 \mathrm{mg} / \mathrm{kgBB}$ sebagai dosis tertinggi. Dosis tengah didapatkan dengan rumus perhitungan sebagai berikut:

$$
\begin{aligned}
\text { Dosis tengah } & =\sqrt[n-1]{\frac{\text { Dosis terbesar }}{\text { Dosis terkecil }}} \\
& =\sqrt[3-1]{\frac{300}{50}}=2,4 \text { kalinya }
\end{aligned}
$$

$$
\begin{aligned}
\text { Dosis tengah } & =\text { Dosis terkecil x 2,4 } \\
& =50 \mathrm{mg} / \mathrm{kgBB} \times 2,4 \\
& =120 \mathrm{mg} / \mathrm{kgBB}
\end{aligned}
$$

Oleh karena itu, pemberian ekstrak etanol bawang putih digunakan 3 dosis bertingkat yaitu 50, 120, dan $300 \mathrm{mg} / \mathrm{kgBB}$. Gentamisin yang digunakan sebagai agen nefrotoksik diberikan pada tikus secara intraperitonial dengan dosis $100 \mathrm{mg} / \mathrm{kgBB}$ (Dehghani et al., 2011)

\section{Pemodelan hewan uji}

Tikus diaklimatisasi terlebih dahulu terhadap kondisi lingkungan selama 7 hari. Kemudian tikus diinduksi gentamisin 100 $\mathrm{mg} / \mathrm{kgBB}$ secara intraperitonial (i.p) satu kali sehari selama 10 hari (Dehghani et al., 2011). Pemantauan kadar BUN dan serum kreatinin dilakukan pada hari ke-0 (baseline) dan hari ke-10 dengan mengambil darah melalui vena orbitalis tikus sebanyak kurang lebih $1 \mathrm{~mL}$. Darah yang sudah diambil didiamkan terlebih dahulu selama 5 menit dan disentrifuse dengan kecepatan 12000 rpm selama 5 menit, selanjutnya diambil bagian supernatan (beningan). Pemeriksaan kadar protein urin menggunakan dipstick urin yang dicelupkan ke dalam urin yang telah ditampung sebelumnya (urin 24 jam), dan hasil langsung dibaca dengan mencocokkan warna dengan warna standard pada dipstik urin (semikuantitatif).

\section{Perlakuan hewan uji}

Penelitian ini dinyatakan lolos etik dengan surat kelayakan etik No. 1370/A.1/KEPK-FKUMS/VIII/2018.

Sebanyak 25 ekor tikus putih jantan galur Wistar yang dibagi dalam 5 kelompok diukur kadar BUN, serum kreatinin dan protein urin sebagai baseline. Perlakuan terdiri dari kontrol normal (aquadest), kontrol negatif gentamisin $(\mathrm{G})$ dan pemberian dosis ekstrak etanol bawang putih (EEBP) selama 10 hari berturut-turut. Pembagian kelompok setiap perlakuan sebagai berikut:

KI diberi aquadest p.o (kontrol normal)

KII diberi aquadest p.o dan gentamisin 100 $\mathrm{mg} / \mathrm{kgBB}$ i.p (kontrol negatif)

KIII diberi EEBP $50 \mathrm{mg} / \mathrm{kgBB}$ p.o dan gentamisin $100 \mathrm{mg} / \mathrm{kgBB}$ ip

KIV diberi EEBP $120 \mathrm{mg} / \mathrm{kgBB}$ p.o dan gentamisin $100 \mathrm{mg} / \mathrm{kgBB}$ i.p

$\mathrm{KV}$ diberi EEBP $300 \mathrm{mg} / \mathrm{kgBB}$ p.o dan gentamisin $100 \mathrm{mg} / \mathrm{kgBB}$ ip.

Pemberian gentamisin i.p dan ekstrak etanol bawang putih p.o dijeda selama 3 jam. Kadar BUN, serum kreatinin dan protein urin diukur pada hari ke-0 (awal) dan 24 jam setelah hari ke-10.

\section{Penentuan kadar BUN}

Kadar BUN ditentukan menggunakan reagen kit Urea FS* (DiaSys). Kadar BUN diukur menggunakan spektrofotometer UV pada panjang gelombang $(\lambda) 340 \mathrm{~nm}$.

Kadar BUN $(\mathrm{mg} / \mathrm{dL})=$ konsentrasi urea (mg/dL) x faktor konversi (0.467).

\section{Penentuan kadar serum kreatinin}

Kadar serum kreatinin diukur menggunakan reagen kit Creatinine FS* (DiaSys) diukur menggunakan spektrofotometer visibel pada panjang gelombang $492 \mathrm{~nm}$. 


\section{Pemeriksaan protein dalam urin}

Pemeriksaan protein dalam urin dilakukan untuk mengetahui hasil secara kualitatif yang dilakukan dengan cara mencelupkan reagen strip ke dalam urin dengan membandingkan warna dari panel strip dengan warna terdekat pada bagian hasil uji (Prabaswara, 2015). Protein urin diukur menggunakan urin tampung selama 24 jam menggunakan dipstik urin (semi-kuantitatif). Selama pemeriksaan, hewan uji dipuasakan dan diletakkan dalam metabolic cage.

\section{Penentuan indeks ginjal}

Indeks ginjal dihitung berdasarkan perbandingan berat ginjal dibagi berat badan tikus

\section{Analisis data}

Data berupa kadar BUN, kadar serum kreatinin dan kadar protein urin (semikuantitatif) yang diperoleh dianalisis menggunakan SPSS (Statistical Package for Social Sciences). Normalitas data diuji menggunakan Shapiro-Wilk, data yang dimasukkan yaitu baseline sebelum diberi perlakuan (hari ke-0) dan pada pada jam ke24 setelah hari ke-10 untuk mengetahui nilai $\mathrm{p}$ value. Data hasil pengukuran kadar BUN tikus dianalisis menggunakan uji parametrik One Way ANOVA karena data homogen dan terdistribusi normal $(\mathrm{p}>0,05)$ dengan taraf kepercayaan $95 \%$ untuk mengetahui ada tidaknya perbedaan perlakuan. Sedangkan data hasil pengukuran serum kreatinin tikus dianalisis dengan uji non parametrik (Kruskal-Wallis) karena pada uji normalitas menunjukkan data terdistribusi tidak normal ( $<<0,05)$ dan dilanjutkan ke uji MannWhitney untuk mengetahui ada tidaknya perbedaan tiap kelompok perlakuan.

\section{HASIL DAN PEMBAHASAN}

Penelitian ini dilakukan untuk menilai pengaruh ekstrak etanol bawang putih dalam perbaikan fungsi ginjal tikus akibat induksi gentamisin dengan parameter serum kreatinin, BUN, dan proteinuria (semikuantitatif). Proses ekstraksi umbi bawang putih dilakukan dengan metode maserasi menggunakan pelarut etanol $96 \%$ dengan perbandingan 3:10 sebagai penyarinya. Bawang putih digunakan karena memiliki kandungan senyawa seperti allisin, S-allil sistein yang mempunyai aktivitas sebagai antioksidan yang berperan dalam meningkatkan sitoproteksi terhadap senyawa asing dan radikal bebas (Rahman et al., 2012; Colin-Gonzalez et al., 2012). Etanol 96\% bersifat polar sehingga diharapkan dapat melarutkan senyawa allisin di dalam umbi bawang putih yang bersifat polar juga (Rahman et al., 2012). Pada ekstraksi bawang putih dipilih metode maserasi karena selain praktis, juga dapat mencegah hilangnya zat penting ketika proses ekstraksi dan menjaga zat aktif dari kerusakan pada senyawa yang termolabil (Prasonto et al., 2017). Dari 620 gram bawang putih yang sudah dihaluskan menghasilkan ekstrak kental sebanyak 25 gram (rendemen 4,03\%).

Langkah selanjutnya yaitu uji in vivo untuk melihat khasiat ekstrak etanol bawang putih terhadap penurunan kadar kreatinin, BUN, dan protein dalam urin. Uji in vivo dimulai dengan membuat permodelan hewan uji menggunakan tikus yang diinduksi gentamisin $\quad 100 \quad \mathrm{mg} / \mathrm{kgBB} \quad$ secara intaperitonial (i.p) (Dehghani et al., 2011). Gentamisin adalah antibiotik golongan aminoglikosida yang bersifat sangat polar sehingga absorbsi gentamisin secara per oral rendah, oleh karena itu gentamisin diberikan secara parenteral. (Mohan et al., 2015)

Efek samping gentamisin sebagian besar dapat mempengaruhi ginjal (nefrotoksisitas) pada 10-20\% kasus terapi, gangguan saraf (neurotoksisitas) dan pendengaran (ototoksisitas) (Lintong et al., 2012). Sitotoksisitas gentamisin terjadi pada sel-sel dimana obat tersebut terakumulasi. Pada ginjal, akumulasi terjadi pada sel-sel epitelial korteks, terutama pada bagian tubulus proksimal, tubulus distal, dan duktus pengumpul. Tingginya akumulasi obat yang terjadi menginduksi terjadinya ekspresi 


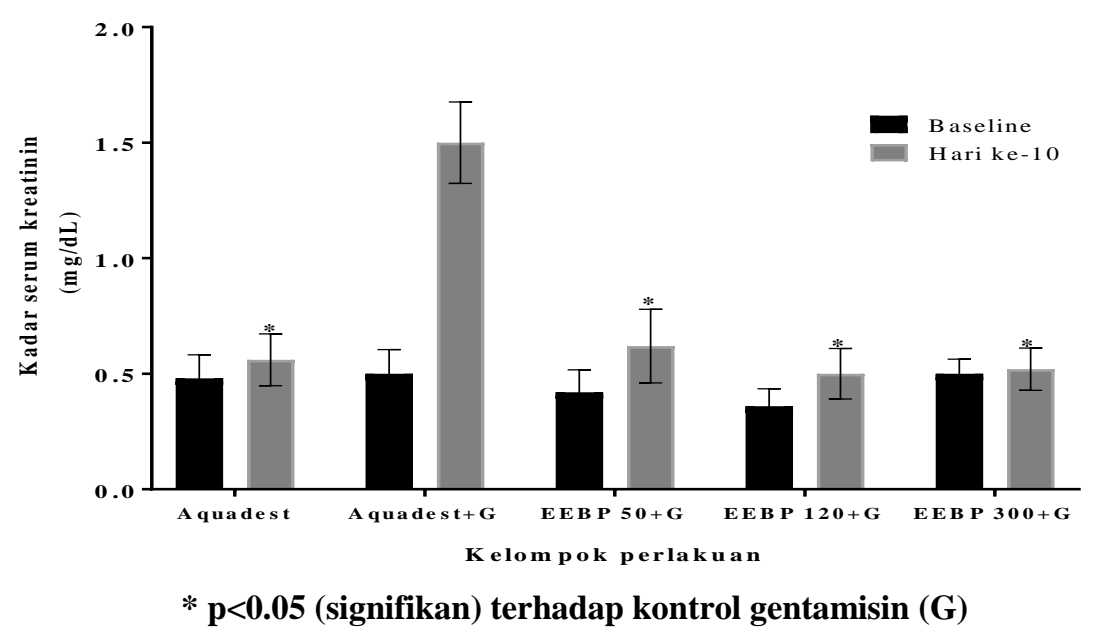

Gambar 1. Kadar serum kreatinin (mean \pm SEM) pada hari ke-0 (baseline) dan setelah perlakuan ekstrak etanol bawang putih (EEBP) selama 10 hari pada tikus yang diinduksi gentamisin $(\mathbf{n}=5)$

transporter dan menyebabkan terbentuknya kompleks endositik oleh kubulin dan megalin, yang terbatas pada tubulus proksimal. Terbentuknya kompleks tersebut digunakan oleh gentamisin untuk bisa masuk ke dalam sel (proses endositosis). Setelah obat masuk ke dalam kompartemen endosomal, gentamisin akan terakumulasi pada retikulum endoplasma (RE), lisosom, dan aparatus golgi, dan menyebabkan terjadinya phospholipidosis yang berkaitan erat dengan tingkat toksisitas gentamisin pada sel-sel epitelial korteks. Sedangkan akumulasi gentamisin pada sitosol dapat menginduksi apoptosis melalui aktivasi jalur intrinsik langsung maupun tidak langsung dalam mitokondria, dengan mengganggu rantai pernafasan, mengganggu produksi ATP, dan menghasilkan stres oksidatif akibat peningkatan hidroksil radikal dan anion superperoksida yang selanjutnya berkontribusi dalam menginduksi kematian sel (Lopez-Novoa et al., 2011).

Setelah tikus diinduksi gentamisin terlihat adanya peningkatan kadar serum kreatinin (Gambar 1), Blood Urea Nitrogen (Gambar 2), protein urin (Gambar 3).

Berdasarkan Gambar 1 terlihat adanya kenaikan kadar kreatinin akibat induksi gentamisin. Pada kontrol negatif terjadi kenaikan kadar kreatinin 3 kali lipat dibandingkan baseline yaitu 1,50 $\pm 0,39$ $\mathrm{mg} / \mathrm{dL}$. Kenaikan kadar kreatinin ini terjadi akibat peningkatan Reactive oxygen species (ROS) di dalam sitosol yang diinduksi oleh gentamisin $100 \mathrm{mg} / \mathrm{kgBB}$ (Lopez-Novoa et al., 2011). Reactive oxygen species yang berlebihan dapat menyebabkan stres oksidatif dan mengakibatkan kerusakan sel, jaringan, hingga organ di dalam tubuh (Khaira, 2010). Peningkatan kadar kreatinin di dalam darah menunjukkan kerusakan terhadap fungsi ginjal dan sebanding dengan penurunan fungsi ginjal. Kadar serum kreatinin normal pada tikus Wistar yaitu 0,30-0,50 $\mathrm{mg} / \mathrm{dL}$ (Fitria et al., 2019). Berdasarkan Gambar 1, perbandingan rerata kadar $\mathrm{sCr}$ pada masingmasing perlakuan mengalami peningkatan jika dibandingkan dengan kadar sCr baseline, akan tetapi masih dalam rentang normal kecuali pada kontrol negatif yaitu terjadi peningkatan menjadi 3 kalinya baseline. Hal ini membuktikan bahwa terjadi penurunan fungsi ginjal akibat induksi gentamisin 100 $\mathrm{mg} / \mathrm{kgBB}$. Hasil analisis statistik menunjukkan bahwa ekstrak etanol bawang putih menurunkan kadar sCr secara signifikan $(\mathrm{p}<0,05)$. Hasil uji perbandingan berganda 


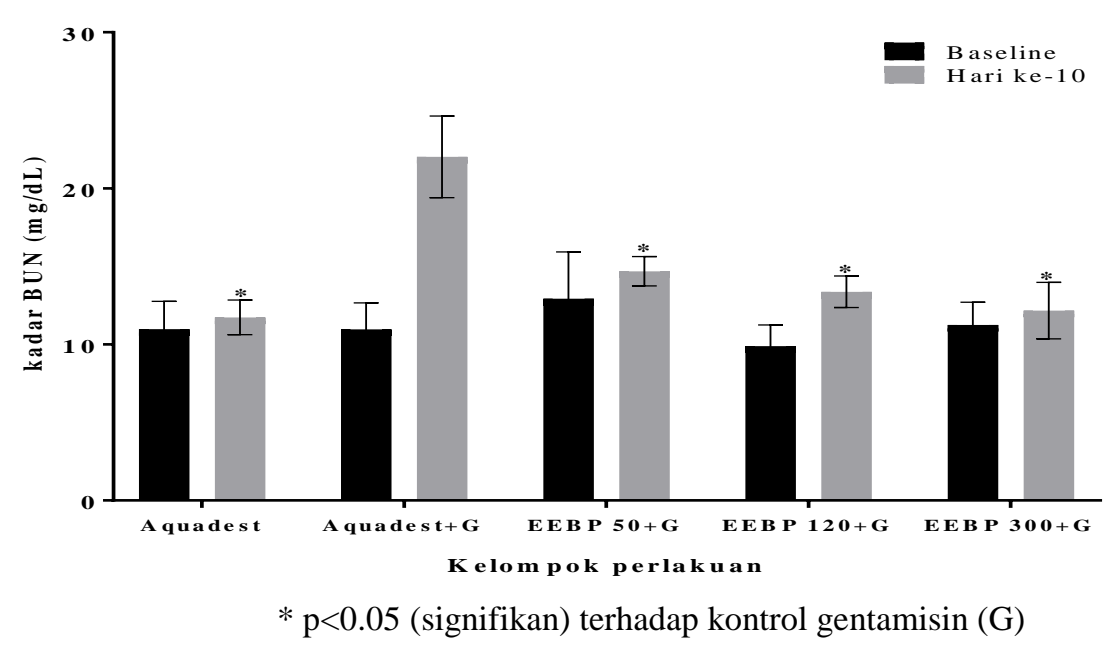

Gambar 2. Kadar Blood Urea Nitrogen (BUN) (mean \pm SEM) pada hari ke-0 (baseline) dan setelah perlakuan ekstrak etanol bawang putih (EEBP) selama 10 hari pada tikus yang diinduksi gentamisin $(\mathbf{n}=5)$

metode Bonferroni menunjukkan adanya perbedaan yang bermakna antara kelompok kontrol negatif (gentamisin) dengan kelompok EEBP pada dosis 50, 120, dan 300 $\mathrm{mg} / \mathrm{kgBB}(\mathrm{p}<0,05)$. Peningkatan dosis tidak menunjukkan adanya peningkatan efek dalam menurunkan kadar serum kreatinin $(\mathrm{p}>0.05)$. Hal ini sesuai dengan penelitian yang sudah dilakukan sebelumnya bahwa ekstrak etanol bawang putih dosis 150 dan $300 \mathrm{mg} / \mathrm{kgBB}$ dapat mencegah terjadinya peningkatan radikal bebas pada sel-sel epithelial korteks (Anusuya et al., 2013) .

Gentamisin ip dosis $100 \mathrm{mg} / \mathrm{kgBB}$ mampu meningkatkan kadar BUN pada tikus. Dari gambar 2 terlihat adanya kenaikan 2 kali lipat nilai rerata kadar BUN pada kontrol negatif dibandingkan baseline. Peningkatan ini terjadi akibat tertahannya urea dalam darah yang tidak bisa dikeluarkan melalui urin. Blood Urea Nitrogen (BUN) adalah produk hasil buangan dari protein. Darah mengangkut protein ke dalam sel, dan setelah protein dipakai oleh sel, sisa produk buangan akan dikembalikan ke dalam darah dalam bentuk urea yang mengandung nitrogen. Pada ginjal yang sehat BUN akan disaring dari darah dan dikeluarkan melalui urin, sedangkan pada ginjal yang sudah tidak berfungsi dengan baik, urea akan tetap tertahan di dalam darah. Oleh karena itu, peningkatan kadar BUN di dalam darah menjadi salah satu indikator terjadinya gangguan pada ginjal (Mohan et al., 2015). Kadar BUN normal pada tikus Wistar adalah 13,37-21,49 mg/dL (Widyastuti et al., 2019). Pada Gambar 2 juga terlihat adanya peningkatan nilai rerata kadar BUN semua kelompok perlakuan jika dibandingkan dengan kadar BUN baseline, namun peningkatan kadar BUN pada kelompok EEBP dosis 50, 120, dan $300 \mathrm{mg} / \mathrm{kgBB}$ masih dalam rentang batas normal. Hasil uji statistik dengan Mann-Whitney menunjukkan adanya perbedaan yang bermakna antara kelompok kontrol negatif dengan kelompok kontrol normal dan EEBP dosis $50 \mathrm{mg} / \mathrm{kgBB}$, EEBP $120 \mathrm{mg} / \mathrm{kgBB}$, dan EEBP $300 \mathrm{mg} / \mathrm{kgBB}$ $(\mathrm{p}<0,05)$. Hasil uji ini menunjukkan bahwa ekstrak etanol bawang putih dapat menurunkan kadar BUN tikus secara signifikan pada dosis 50, 120, dan 300 $\mathrm{mg} / \mathrm{kgBB}$.

Uji lain yang digunakan sebagai parameter kerusakan ginjal adalah uji semikuantitatif proteinuria yang digunakan sebagai data pendukung terjadinya gangguan fungsi ginjal menggunakan dipstik urin (Gambar 3). Ginjal bertanggung jawab dalam mengekskresikan senyawa toksik dalam 


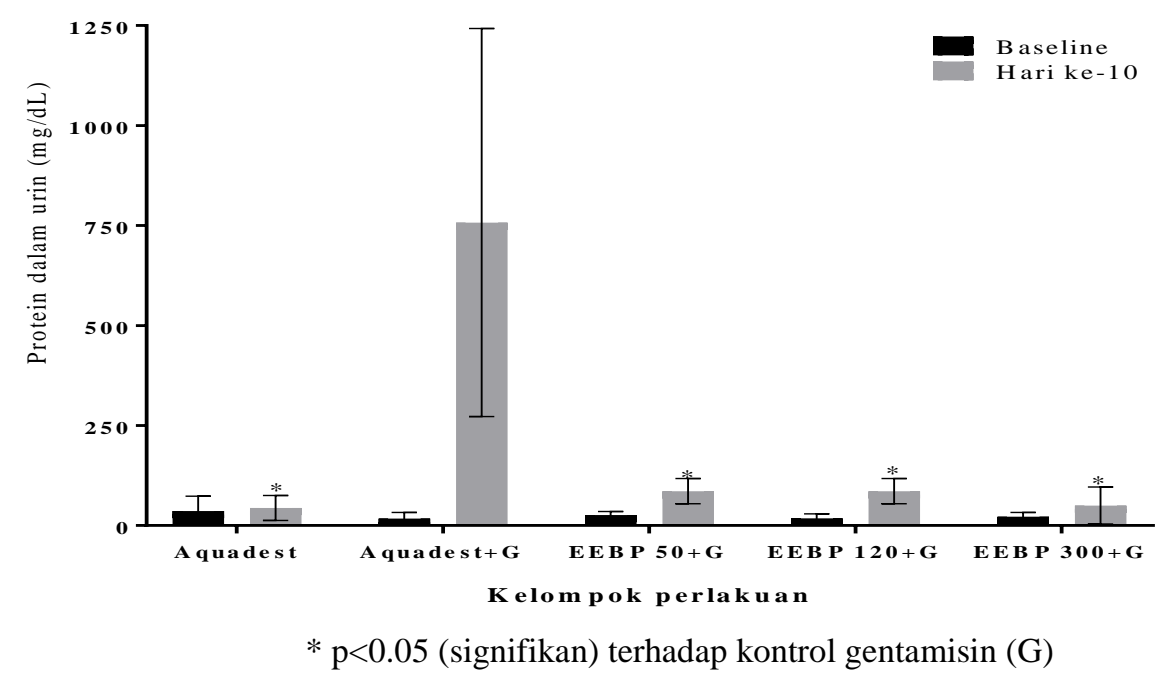

Gambar 3. Kadar protein urin (mean \pm SEM) pada hari ke-0 (baseline) dan setelah perlakuan ekstrak etanol bawang putih (EEBP) selama 10 hari pada tikus yang diinduksi gentamisin $(n=5)$

tubuh yang sudah tidak diperlukan lagi melalui urin (Gowda et al., 2010). Oleh karena itu, pemeriksaan profil urin dilakukan untuk mengetahui zat-zat yang dalam keadaan normal tidak terdapat di dalam urin atau perubahan kadar zat yang dalam keadaan normal terdapat dalam urin, salah satunya adalah protein urin. Pada ginjal yang masih berfungsi dengan baik, protein akan tersaring oleh glomerulus sehingga tidak keluar bersama urin.

Berdasarkan Gambar 3 terjadi peningkatan rerata kadar protein urin pada kelompok kontrol normal dan kontrol dosis setelah perlakuan jika dibandingkan dengan kadar protein urin baseline. Akan tetapi peningkatan kadar protein urin masih dalam rentang normal yaitu kurang dari $100 \mathrm{mg} / \mathrm{dL}$. Berbeda dengan kontrol negatif, dimana peningkatan rerata kadar protein urin terjadi melebihi batas normal yaitu 757,50 $\pm 242,50$ $\mathrm{mg} / \mathrm{dL}$ (meningkat 10 kalinya). Peningkatan rerata kadar protein urin ini terjadi karena glomerulus merupakan bagian pertama dari ginjal yang kontak dengan agen kimia. Gentamisin dapat menyebabkan perubahan filtrasi glomerulus dengan beberapa mekanisme yaitu dengan perubahan morfologi yaitu terjadinya pembengkakan pada glomerulus, menginduksi terjadinya kontraksi pada mesangial sehingga menyebabkan terjadinya pengurangan GFR, memicu terjadinya proliferasi mesangial, peningkatan apoptosis sel-sel glomerulus, dan menghilangkan barier selektif pada filtrasi glomerulus sehingga dapat menyebabkan proteinuria (Lopez-Novoa et al., 2011)

Tabel 1. Efek pemberian ekstrak etanol bawang putih (EEBP) terhadap profil indeks renal (mean \pm SD) $(\mathbf{n}=\mathbf{3})$

\begin{tabular}{lccc}
\hline Kelompok & $\begin{array}{c}\text { Berat } \\
\text { ginjal }(\mathrm{g})\end{array}$ & $\begin{array}{c}\text { Berat badan tikus hari } \\
\text { ke-10 }(\mathrm{g})\end{array}$ & Rasio ginjal \\
\hline Akuades & $0,55 \pm 0,04$ & $125,33 \pm 20,31$ & $0.89 \pm 0,08$ \\
Akuades+G & $0,86 \pm 0,06$ & $154,67 \pm 25,42$ & $1,12 \pm 0,12$ \\
EEBP 50+G & $0,62 \pm 0,08$ & $150,67 \pm 8,62$ & $0,83 \pm 0,07$ \\
EEBP 100+G & $0,66 \pm 0,07$ & $133,67 \pm 6,03$ & $0,99 \pm 0,15$ \\
EEBP 200+G & $0,82 \pm 0,18$ & $164,33 \pm 29,91$ & $1,00 \pm 0,14$ \\
(Gentamisin); EEBP $($ Ekstrak Etanol Bawang Putih dosis 50, 120, dan 300 mg $/ \mathrm{kgBB})$
\end{tabular}


Dari uji ini menunjukkan bahwa ekstrak etanol bawang putih dengan dosis 50,120,300 $\mathrm{mg} / \mathrm{kgBB}$ dapat menurunkan kadar protein urin dalam rentang normal yaitu $<100 \mathrm{mg} / \mathrm{dL}$.

Ekstrak etanol bawang putih dapat menurunkan indeks ginjal. Kontrol nefrotoksik gentamisin menunjukkan indeks ginjal paling tinggi dibanding kelompok kontrol dan kelompok perlakuan EEBP meskipun perbedaannya tidak signifikan (p>0,05) (Tabel 1).

Perhitungan rasio bobot ginjal dan berat badan tikus dilakukan untuk mengoreksi faktor berat badan, tikus yang memiliki berat badan lebih besar akan memiliki berat ginjal yang lebih besar pula.

\section{KESIMPULAN}

Berdasarkan hasil penelitian yang telah dilakukan, dapat disimpulkan bahwa ekstrak etanol bawang putih dengan dosis 50, 120, dan $300 \mathrm{mg} / \mathrm{kgBB}$ dapat mencegah penurunan fungsi ginjal pada tikus akibat induksi gentamisin dengan parameter serum kreatinin (sCr) dan Blood Urea Nitrogen (BUN).

\section{Daftar Pustaka}

Anusuya, N., Durgadevi, P., Dhinek, A., and Mythily, S., 2013. Nephroprotective Effect of Ethanolic Extract of Garlic (Allium sativum L.) on Cisplatin Induced Hephrotoxicity in Male Wistar Rats 6, 6-9.

Colin-Gonzalez, A.L., Santana, R.A., Silva-Islas, C.A., Chanez-Cardenas, M.E., Santamaria, A., and Maldonado, P.D., 2012, The Antioxidant Mechanisms Underlying the Aged Garlic Extract and S-allylcysteine-Induced Protection, Oxidative Medicine and Celluler Longevity, doi : 10.1155/2012/907162

Dehghani, F., Namavar, M.., Noorafshan, A., Karbalay-Doust, and Esmaeilpour, T., 2011. Evaluation of the Kidney Extract on Gentamicin Induced-Nephrotoxicity in Rat. Kidney Res. J. 1, 24-32.

Fitria, L., Lukitowati, F., and Kristiawati, D., 2019, Nilai Rujukan untuk Evaluasi Fungsi Hati dan Ginjal pada Tikus (Rattus norvegicus Berkenhout, 1769) Galur Wistar, Jurnal Pendidikan Matematika dan IPA,10 (2), 243-258

Gounden, V., and Jialal, I., 2019. Renal Function Tests. StatPearls Publishing.

Gowda, S., Desai, P.B., Kulkarni, S.S., Hull, V.V., Math, A.A.K and Vernekar, S.N., 2010, Markers of renal function test, N Am J Med Sci, 2 (4), 170-173

Khaira, K., 2010. Menangkal Radikal Bebas dengan Anti-Oksidan. J. Saintek II, 183-187.

Lintong, P.M., Kairupan, C.F., and Sondakh, P.L.N., 2012. Gambaran Mikroskopik Ginjal Tikus Wistar (Rattur norvegicus) setelah Diinduksi dengan Gentamisin. J. Biomedik 4, 185-192.

Lopez-Novoa, J.M., Quiros, Y., Vicente, L., Morales, A.I., and Lopez-Hernandez, F.J., 2011. New Insights Into the Mechanism of Aminoglycoside Nephrotoxicity : an Integrative Point of View. Kidney Int. 79, 33-45. https://doi.org/10.1038/ki.2010.337

Mohan, M., Shetty, D., Shetty, T., and Banerjee, S., 2015. Gentamicin : Myths and Truths. Nitte Univ. J. Heal. Sci. 5, 4-7.

Pearce, E.C., 2013. Anatomi dan Fisiologi untuk Paramedis. PT Gramedia Pustaka Utama, Jakarta. 
Prabaswara, F.G., 2015. Profil Kimia Urin Tikus Putih setelah Diberi Ekstrak Etanol Lempuyang Gajah (Zingiber zerumbet) selama 28 Hari. Universitas Muhammadiyah Surakarta.

Prasonto, D., Riyanti, E., and Gartika, M., 2017, Uji Aktivitas Antioksidan Ekstrak Bawang Putih (Allium sativum), Dental Journal, 4 (2), 122-128

Rahman, M.M., Fazlic, V., and Saad, N.W., 2012, Antioxidant Properties of Raw Garlic (Allium sativum) Extract, International Food Research Journal, 19 (2), 589-591

Widyastuti, D.A., Ristianti, M.A., and Sari, I.M., 2019, The Study of Blood Creatinin and Urea Concentration of Wistar Rats (Rattus norvegicus) due to Sodium Nitrite Induction, Jurnal Ilmu Kefarmasian Indonesia, Vol 17, No 1, 14-20 